\title{
USER ENGAGEMENT MECHANISMS OF ONLINE CO-DESIGN SERVICE: DOES USER INNOVATIVENESS MATTER?
}

\author{
Nila A. Windasari ${ }^{1,2 *}$ and Luksi Visita ${ }^{3}$ \\ ${ }^{1}$ Institute of Service Science, National Tsing Hua University, No. 101 Section 2, \\ Kuang-Fu Road, Hsinchu, Taiwan \\ ${ }^{2}$ School of Business and Management, Bandung Institute of Technology, \\ Jl. Ganesha No. 10, Bandung, Indonesia \\ ${ }^{3}$ Faculty of Economics and Islamic Business, Universitas Islam Negeri - Walisongo, \\ Jl. Prof. Dr. Hamka, 3rd Campus UIN Walisongo, Ngaliyan, Semarang, Indonesia \\ *Corresponding author: nila.armelia@sbm-itb.ac.id
}

Published online: 27 June 2019

To cite this article: Windasari, N.A. and Visita, L. (2019). User engagement mechanisms of online co-design service: Does user innovativeness matter? Asian Academy of Management Journal, 24(1), 59-82. https://doi.org/10.21315/aamj2019.24.1.3

To link to this article: https://doi.org/10.21315/aamj2019.24.1.3

\begin{abstract}
The customer's shifting role makes collaboration between customer and service provider one of the most important aspects in the value co-creation process. The collaboration and active user's role has prompted co-design to become one of the strategies for successful product development. This research proposes engagement mechanism factors that improve user engagement and encourage customers to use and buy through the co-design web service. The factors are interactive feedback with the service provider and collecting points from social media sharing. We also propose user innovativeness to moderate the predictors and improve user engagement. We utilise a scenario-based experiment for a co-design clothing web store in Indonesia. Results show that additional interactive contact with the service provider will increase a user's engagement and likelihood of use. The effect is greater for customers with lower levels of innovativeness. In contrast, adding game elements (e.g., points) has no significant contribution to customer engagement and use intention. This research shows the value of engagement mechanisms in enabling the value co-creation process in a co-design platform. This study contributes by providing a framework for the service provider to deploy an engaging co-design service by considering both service provider factors (i.e., engagement mechanics embedded on the web) and
\end{abstract}

(C) Asian Academy of Management and Penerbit Universiti Sains Malaysia, 2019. This work is licensed under the terms of the Creative Commons Attribution (CC BY) (http://creativecommons. org/licenses/by/4.0/). 
customer-related factors (i.e., user innovativeness level) to encourage customers to use and buy through online co-design service.

Keywords: co-creation, co-design, customer engagement, customer experience, user innovativeness

\section{INTRODUCTION}

Online web service is one of the most promising and integral services provided by companies nowadays. On the other hand, the customers' role is shifting greatly, as what they are experiencing before, during, and after purchasing (Ostrom et al., 2015). Traditionally, people used online services as a medium of transaction, to replace direct interaction and simplify the transaction process; but today, customers are more interested in creating value and makes collaboration between customer and service provider which has become necessity in value co-creation process (Zhang, Lu, \& Kizildag, 2017).

Co-design as the general practice of involving a user in designing products and services for him/herself is not a recent approach. Architects, software engineers, and system developers initially used the co-design concept to develop a user-friendly and practical application. Now, after further development, co-design as part of customisation is seen as an important step to fulfilling the individual customers' needs (Piller, Schubert, Koch, \& Möslein, 2005), since it enables customers to collaborate with the service provider. Examples of co-design applications include Canva (canva.com) and NIKEiD (www.NIKEiD.com). These websites allow people to customise the design of creative media and shoes so that the design fits customers' desires.

Although the co-design website is gaining popularity and can cater to customers' demands for self-customisation, it is unclear if it can be a sustainable business model in the long-run. The sustainability of this type of business is driven by the user's willingness to use and buy through it. Considering the trending phenomena of co-design website in the online market and theoretical implication of the sustainable service, our research focus on engaging customers who intend to use and purchase through this type of online service. User engagement in the service occurs in the encounter stage (Tsiotsou \& Wirtz, 2012). Therefore, engaging web design as a co-design platform plays a significant role in immersing the customer. Engagement is a compulsory factor in human-computer interaction (Laurel, 1993) and is vital for success in a co-design project (Opromolla, 2015). A user's lack of engagement will jeopardise the potentiality of reusing the co-design website, or worse, will compromise purchases through the co-design website. 
One of the basic struggles co-design providers face is altering the value creation process. Prahalad and Ramaswamy (2004) posited that, in the past, value was centred on the product; in the modern world, customers view value as a personal experience, so value creation is situated in their hands. To unravel this problem and for further analysis, we utilised service-dominant logic (SDL) and flow theory.

SDL relies heavily on the collaboration and network of a user and an organisation (Lusch, Vargo, \& O'Brien, 2007), and value can be achieved by increasing user engagement. This assumption is sensible since co-creation is a result of interactions among involved parties (Lusch \& Vargo, 2014). High user engagement is expected to encourage users to keep using the co-design service.

According to flow theory, involvement, engagement, and experience are factors causing customers to return to shop on certain websites. Flow theory is used due to its ability to explain emotional and cognitive components that are involved during the online experience (Koufaris, 2002). Several mechanisms can be applied on the design, such as gamification elements and interactive feedback that can create reciprocal interaction and make customer feel more engaged. Involved users are expected to enjoy their experience using the co-design website and subsequently make more purchases. As a result, return purchases and customer retention will sustain a co-design service.

Literatures strongly emphasise co-design and co-creation, but most research emphasises two distinct streams: the user's perspective (Son, Sadachar, Manchiraju, Fiore, \& Niehm, 2012) and technical design. Since designing an engaging website is inseparable from individual behaviour and the customer is the centre of the cocreation process, customer's innate factor such as user innovativeness is crucial. A customer using an online service is an information technology (IT) user (Koufaris, 2002). Individual differences, concerning level of innovativeness in using IT, must be explored due to their impact on users' intentions to use online services (Kwon, Choi, \& Kim, 2007). Our research sheds light by examining engagement factors from both service provider factors (i.e., technical engagement mechanics embedded on the web) and customer-related factors (i.e., user innovativeness levels) as potential research directions in deploying co-design services.

Our research examines the effect of engagement mechanics on improving customer engagement and use intention on co-design web service. We also aim to explore the role of user innovativeness as an individual factor, which can moderate the relationship between engagement mechanics and use intentions. We use an empirical study using a scenario-based experiment with two factors - interactive feedbacks and game mechanics - as proxies for engagement mechanics to attract 
customers using a co-design web service. Our research contributions could be applied to enrich the understanding of engagement mechanics development for both co-design service providers and consumer behaviour literature.

\section{LITERATURE REVIEW}

\section{Co-Creation and Co-Design in Online Service}

Co-design in a broader sense refers to the creativity of designers and people not trained in design working together in the design development process. This research considers co-design web service a practice of co-creation between the service provider's designer and the customer. Customers might bring their own product requests and innovation that are distinct from the companies' point of view, and service providers can offer a meaningful experience for the customer during the process.

With the evolution of the user's role, co-design is gaining popularity and user in parallel with co-creation (Sanders \& Stappers, 2008). We explain differences in the literature review in Table 1 to limit our focus and avoid discussion bias.

Table 1

Differences between co-design, co-production, and co-creation

\begin{tabular}{|c|c|c|c|}
\hline Criteria & Co-design & Co-production & Co-creation \\
\hline $\begin{array}{l}\text { Customer } \\
\text { involvement }\end{array}$ & $\begin{array}{l}\text { Users define, configure, } \\
\text { or modify their own } \\
\text { solutions from a list of } \\
\text { options and components } \\
\text { (from producer) } \\
\text { (Koskela-Huotari, } \\
\text { Friedrich, \& Isomursu, } \\
2013 \text { ) }\end{array}$ & $\begin{array}{l}\text { Role of customer is } \\
\text { passive and firm-centric } \\
\text { (Payne, Storbacka, \& } \\
\text { Frow, 2008; Chathoth, } \\
\text { Altinay, Harrington, } \\
\text { Okumus, \& Chan, 2013) }\end{array}$ & $\begin{array}{l}\text { Role of customer is } \\
\text { active, more customer- } \\
\text { and experience-centric } \\
\text { (Chathoth et al., 2013) }\end{array}$ \\
\hline $\begin{array}{l}\text { Steps and } \\
\text { process }\end{array}$ & $\begin{array}{l}\text { Define a problem and } \\
\text { then define a solution } \\
\text { (McDougal, 2012) }\end{array}$ & $\begin{array}{l}\text { Implement the } \\
\text { proposed solution } \\
\text { (McDougal, 2012) }\end{array}$ & $\begin{array}{l}\text { Both, encompass the } \\
\text { entire process of design } \\
\text { and production } \\
\text { (McDougal, 2012) }\end{array}$ \\
\hline Relationships & $\begin{array}{l}\text { Part of co-creation and } \\
\text { co-production (Koskela- } \\
\text { Huotari et al., 2013) }\end{array}$ & \multicolumn{2}{|c|}{$\begin{array}{l}\text { Co-production and co-creation are related and } \\
\text { interchangeable } \\
\text { (Voorberg, Bekkers, \& Tummers, 2015) }\end{array}$} \\
\hline Phase & $\begin{array}{l}\text { Product development } \\
\text { process } \\
\text { (Shaukat, Gonzalez, \& } \\
\text { Saltou, 2014) }\end{array}$ & $\begin{array}{l}\text { Production stage } \\
\text { (Koskela-Huotari et al., } \\
\text { 2013) }\end{array}$ & $\begin{array}{l}\text { Consumption and } \\
\text { usage (Kristensson, } \\
\text { Matthing, \& } \\
\text { Johansson, 2008) }\end{array}$ \\
\hline
\end{tabular}


In our research, we use co-design to discuss how service providers enable value co-creation with their customers. The general concept of co-design reflects the idea of working with end-users. The customer is viewed as co-originator, co-creator, and co-constructor (Udwadia \& Kumar, 1991). In several publications, co-design is also viewed as a collaborative relationship between customer and manufacturers wherein, through a process of interaction, the product is designed according to customer specification and based on manufacturing components the product's design (Lowyck \& Pöysä, 2001; Romero \& Molina, 2011; Ulrich, Jo AndersonConnell, \& Wu, 2003).

Co-design activities are performed through company-to-customer interaction. In the platform where co-design is performed, service providers use toolkits in their web design for customers to co-design. This platform enables user to interact with the service provider, either directly through the customer service or designer to ask for feedback, or indirectly through user guidelines help or wiki. Therefore, co-design system features must be user-friendly and effective (Ulrich et al., 2003) to make a user enjoy his/her interaction with the website. An effective system enables interactive communication between the user and service provider. Thus, in this study, we use interactive feedback from designer of the service provider to represent an effective web-mediated interaction.

Besides the transactional side of the relationship, engagement has been shown to affect customer lifetime value (CLV) and firm value (Verhoef, Reinartz, \& Krafft, 2010). Pursuing new business models like co-design web services could help both users and service providers obtaining more efficient services. This type of service enables the sharing of knowledge and resources through welcoming outside ideas. The company will simultaneously gain better price competition positioning in the market. As the design costs decrease, the customer can get a lower price for the desired product. Ultimately, this practice will benefit both parties and strengthen customer relationships.

\section{User Engagement: SDL and Flow Theory}

With the customer's expanded role, a common belief posits that online services should capture all cues and encounters that occur before, during, and after the electronic service delivery to enhance customer experience (Bauer, Falk, \& Hammerschmidt, 2006) beyond the service provider's perspective. As a result, we use SDL to explain how a user interacts with the service provider through a web service (Vargo \& Lusch, 2004), as well as flow theory (Csikszentmihalyi, 1977) to explain relevant mechanisms that engage the user. 
SDL emphasises co-creation of value, interactions between actors, and resource sharing. Three implications of SDL are used in this research: (1) the customer's and service provider's roles are equally important (Vargo, Maglio, \& Akaka, 2008); (2) resource sharing is coined as operant resources (FP 4: operant resources are the fundamental source of strategic benefit); and (3) online co-design service enable actors to benefit each other (FP 8: a service-centered view is inherently beneficiary oriented and relational) (Vargo \& Lusch, 2016), not only through the outcome (i.e., sales generated) but through the process as well (i.e., customer engagement during service encounter).

Several literatures recommend flow theory as an approach to understanding user engagement behaviour in an online service context (Koufaris, 2002). Flow theory is described as a state in which "people are so involved in an activity that nothing else seems to matter" (Csikszentmihalyi, 1977) and as a gratifying experience when a person is fully involved in an activity (Csikszentmihalyi \& Rathunde, 1993). The original concept of flow theory is defined as the holistic sensation that people feel when they act with total involvement. In most literature, intention to use an online service is driven from motivation (intrinsic and extrinsic) and technological acceptance (usefulness as well as ease of use). In co-design online services, we underline the importance of user involvement in the process of designing a product they want to purchase. A computer user is also a customer in the web-based store; therefore, it is useful to employ flow theory to study online consumer behaviour (Koufaris, 2002).

\section{Customer Engagement, Engagement Mechanisms, and User Innovativeness}

Customer engagement in co-creating experience and value is receiving increasing attention, and the conceptual root is heavily explored in relationship marketing, particularly using SDL (Brodie, Hollebeek, Jurić, \& Ilić, 2011). Engagement mechanisms can be characterised by attributes of a challenge, positive effect, endurability, aesthetic and sensory appeal, attention, feedback, variety/novelty, interactivity, and perceived user control (O'Brien \& Toms, 2008). The state of flow occurs when an individual is partaking in an activity for its own sake, feels satisfied, and wants to repeat the action regularly. Based on this underlying assumption, there are some web service technical factors that enable a user to feel engaged and later affect their behaviour while using and purchasing through that service. According to flow theory, challenge, feedback, and motivation are relevant to engagement (O’Brien \& Toms, 2008).

Co-design requires a user-friendly and interactive flow web design to motivate users to co-create with their service provider. To fulfil the elements of challenge, 
feedback, and motivation, we chose two factors - interactive contact with the service provider and points from social media sharing - to provide a positive flow experience.

Innovativeness is a key driver of technological acceptance. E-commerce shows a predominance of the concept of innovativeness as a domain-specific variable, defined as the willingness of an individual to try out any new information technology (Agarwal \& Prasad, 1998). It can also be described as the extent of an individual's willingness to experiment with new products or services (San Martin \& Herrero, 2012).

We have proposed external factors (i.e., technical engagement mechanics) affecting customers' tendency to engage in value co-creation process. We further considered internal motivations, such as innovativeness, as exerting equal or even more influence. Research by Franke and Piller (2003) supports the idea that personal characteristics, including innovativeness, impact the experience of flow and satisfaction in customer-driven customisation toolkits. Therefore, we propose user innovativeness as the moderator for engagement mechanisms and use intention, since it can be viewed as an individual factor to use the co-design web service.

\section{HYPOTHESIS DEVELOPMENT}

\section{The Impact of Engagement Mechanism to Use Intention}

According to the definition of flow theory, we used two elements - interaction with the service provider and points from social media sharing - as proxies for engagement mechanics. Using the two manipulated elements, we examined how engagement mechanisms provided by a service provider impact a user's engagement and intention. There are two types of interactivity: human-to-human and humanto-message. In the context of co-design web service, we limited our study into human-to-human interaction for more interactive feedback (compared to that of human-to-message). We used the scenario of a back-end designer (provided by the online co-design service provider) who is available online to help the customer.

Ghose and Dou (1998) identify the roles of interactive feedback on online firms' efforts to build a good relationship with their customers. It shows that interactivity has affected user engagement, including senses of fun, satisfaction, and involvement (Teo, Oh, Liu, \& Wei, 2003). A user can feel dyadic interaction through interactive websites and communication with the service provider through the online platform. 
Interactivity has a significant positive relationship, not only with user engagement, but also with attitudes on using a specific type of technology (Webster \& Hackley, 1997). Furthermore, interaction is critical especially on how commercial web design and usability are perceived by a user. When the user feels more engaged using the site, they will perceive feedback from the website's designer as more useful. A greater perspective towards the website will positively impact purchase intention (Stevenson, Bruner, \& Kumar, 2000). Therefore, we hypothesise the following:

H1a: The presence of feedback from a service provider on a co-design web service will lead to higher user engagement.

H1b: The presence of feedback from a service provider on a co-design web service will lead to higher intention to use.

A second proposed factor that provides positive flow experience is game elements, i.e., points gathered from social media sharing. In the literature, gamification was found to impact user engagement (Muntean, 2011; Flatla, Gutwin, Nacke, Bateman, \& Mandryk, 2011) to generate further user engagement (Deterding, Dixon, Khaled, \& Nacke, 2011) and make interaction more exciting for the user. Several game elements (i.e., points, social media sharing) can be embedded on the websites, such as give credits to a well-designed product to motivate users and provide sharing options to social media. This will allow users to showcase their design to the social media and networked friends, and subsequently fulfill their needs of appreciation and social existence. Gamification is expected to be a predictor of supporting user engagement and improving service use (Hamari, 2013).

In co-design websites, several game features could influence customer behaviour in using and performing additional transactions. It is proven that rich elements/ features associated with games on websites could positively impact the customer's intention to feel more engaged with and use the website (Rodrigues, Costa, \& Oliveira, 2014). Thus, they will spend more time using the website and make more transactions. Therefore, we hypothesise the following:

H2a: The presence of game elements in a co-design web service will lead to higher user engagement.

$\mathrm{H} 2 \mathrm{~b}$ : The presence of game elements in a co-design web service will lead to higher intention to use. 


\section{The Moderating Effect of User Innovativeness}

Co-design uses a strategy to unite user and service provider to elicit user needs through innovative demands. Customers do not possess the same skills and technology efficacy as the designers do, but they can generate ideas that integrate technology with their needs (Kristensson, Magnusson, \& Matthing, 2002). Dabholkar and Bagozzi (2002) suggest that innovativeness in the IT domain acts as a moderator variable on the antecedents and consequences of perceptions about a particular system.

This study utilises user perspectives, which are primarily moderated by specific individual factors. The predictors are derived from flow experiences that affect several behaviours in different magnitudes. We believe that engagement mechanics, such as interaction with the service provider and points, are better utilised and more beneficial to users in different levels of innovativeness. A person with high personal innovativeness might be a risk-lover or early adopter, so personal innovativeness affects his/her behaviour or intention to use the new technology (Agarwal \& Prasad, 1998). Therefore, we hypothesise the following:

H3a: A user with low innovativeness exhibits a higher intention to use in high interactivity settings.

H3b: A user with high innovativeness exhibits a higher intention to use in high gamification settings.

\section{METHODOLOGY}

\section{Research Design}

We utilise a scenario-based survey to address our research problems, since there are no services offering engaging mechanisms embedded into their web platforms. Participants imagining themselves in a situation that can elicit the same reactions as being in the real condition (Montes \& Zweig, 2009). This helps us gain optimum results and more significant responses with fewer resources.

To control the effects of two predictors of flow experience, this study uses an experimental design to manipulate the independent variable. For manipulation, we used $2 \times 2$ between subject scenario design in the presence of feedback (with feedback - no feedback) and presence of points (with points - no points) as shown in Figure 1. 


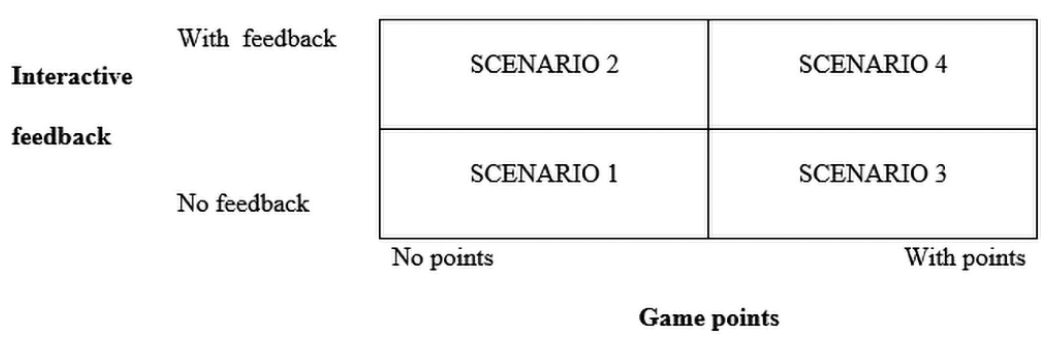

Figure 1. Scenario dimension

The online experiment designed a manipulated website with scenario as drawn in Figure 1. The highest-level engagement mechanics are embedded with two features - interactive chat with designer from the service provider and points from social media sharing - while the lowest level co-design websites are not. Our scenario uses clothing products, which are commonly available in the market and allow participants to imagine real situations. Before formally distributing the scenario-based survey, we conducted a pilot test to adjust the composed scenario, conforming the survey items and scenario context for our targeted participants. We did a back-translation to Bahasa Indonesia because the data were collected from Indonesian participants.

The survey consists of four parts: simple informed consent; personal information; random assignments to the manipulated scenario about co-design websites, which consists of a narrative story and an interface illustration; and survey items measuring other variables from the framework adapted from existing literature (Goldsmith, 2002; San Martin \& Herrero, 2012), which consist of user innovativeness, user engagement, and intention to use and to purchase online.

\section{RESULTS}

\section{Sample Description}

Our study populations are adult Indonesian (aged above 18 years old). We obtained 236 respondents through an online survey, but 23 respondents left in the middle of the survey and did not pass the manipulations checks. From Table 2, it can be seen that majority of the respondents are female, younger than 45 years old $(89 \%)$ and have at least university degree (94\%). 
Table 2

Demographic profile

\begin{tabular}{|c|c|c|}
\hline & Amount & Percentage \\
\hline \multicolumn{3}{|l|}{ Gender } \\
\hline Male & 92 & 43 \\
\hline Female & 121 & 57 \\
\hline \multicolumn{3}{|l|}{ Age } \\
\hline $18-25$ & 71 & 33 \\
\hline $26-35$ & 119 & 56 \\
\hline $36-45$ & 23 & 11 \\
\hline \multicolumn{3}{|l|}{ Education } \\
\hline High school & 13 & 6 \\
\hline Undergraduate & 114 & 54 \\
\hline Postgraduate & 86 & 40 \\
\hline \multicolumn{3}{|c|}{ Computer usage efficacy } \\
\hline $1-3$ & 6 & 3 \\
\hline 4 & 29 & 14 \\
\hline 5 & 63 & 30 \\
\hline 6 & 73 & 34 \\
\hline 7 & 42 & 20 \\
\hline \multicolumn{3}{|c|}{ Computer usage frequency } \\
\hline 1 & 19 & 9 \\
\hline 2 & 27 & 13 \\
\hline 3 & 24 & 11 \\
\hline 4 & 35 & 16 \\
\hline 5 & 39 & 18 \\
\hline 6 & 37 & 17 \\
\hline 7 & 32 & 15 \\
\hline \multicolumn{3}{|c|}{ Prior experience (in using co-design web service) } \\
\hline No & 174 & 82 \\
\hline Yes & 39 & 18 \\
\hline
\end{tabular}

From the aspect of computer usage efficacy, it is known that $84 \%$ of respondents identified themselves as good up to really good computer user ( $\geq 5$ from 7 scales) and $82 \%$ respondents identified themselves as not having experience with similar type of co-design website. 


\section{Reliability and Validity}

Confirmatory factor analysis (CFA) using varimax rotation was used to test the validity as shown in Table 4. Kaiser-Meyer-Olkin (KMO) and Bartlett's tests were performed beforehand, and the result shows that the KMO score is 0.844 (significant at 0.001 level), fulfilling the conditions required by Hair, Black, Babin, and Anderson (2014). Factor loading score for each item of the instruments is more than 0.5 and there is no cross loading among items.

Table 3

Means, standard deviation, and correlation between variables

\begin{tabular}{lcccc}
\hline Variables & Average value & Standard deviation & 1 & 2 \\
\hline Innovativeness & 4.5939 & 1.28167 & & \\
User engagement & 4.2007 & 1.09455 & $0.392^{* *}$ & \\
Intention to use & 5.3439 & 1.12800 & $0.276^{* *}$ & $0.584^{* *}$ \\
\hline
\end{tabular}

Note: $\mathrm{N}=213 ;{ }^{* *}$ correlation significant at the level of 0.01 (2-tailed)

The reliability was tested using Cronbach's alpha. Our results show that all variables have Cronbach's alpha score more than 0.8 and fulfill the minimal requirements for reliability test of 0.7 (Hair et al., 2014). Therefore, all items are reliable for further analysis.

Table 4

Factor loading score

\begin{tabular}{|c|c|c|c|c|}
\hline Items & & 1 & 2 & 3 \\
\hline I feel that I am an innovative person. & INNO1 & & 0.919 & \\
\hline $\begin{array}{l}\text { I like to experiment with the new information } \\
\text { technology. }\end{array}$ & INNO2 & & 0.913 & \\
\hline I feel that I am an innovative person. & INNO3 & & 0.771 & \\
\hline Shopping using this website is very worthy for me. & ENG1 & & & 0.822 \\
\hline I can do anything that I want on this website. & ENG2 & & & 0.820 \\
\hline $\begin{array}{l}\text { I will recommend to shop using this website to my } \\
\text { friends and family. }\end{array}$ & ENG3 & & & 0.772 \\
\hline $\begin{array}{l}\text { If I can use this co-design website to make my own } \\
\text { clothes, I tend to use it. }\end{array}$ & USE1 & 0.896 & & \\
\hline If I can use this co-design website, I think I will use it. & USE2 & 0.858 & & \\
\hline $\begin{array}{l}\text { I tend to use this website to make my own clothes one } \\
\text { day when I want to buy unique clothes. }\end{array}$ & USE3 & 0.879 & & \\
\hline $\begin{array}{l}\text { I decided to use this website in the next opportunity } \\
\text { when I want to buy clothes that I made myself. }\end{array}$ & USE4 & 0.897 & & \\
\hline
\end{tabular}

Note: INNO1-INNO3 measured user innovativeness; ENG1-ENG3 measured user engagement; USE1-USE4 measured intention to use online co-design service 


\section{Hypotheses Testing}

To test the engagement mechanism effect, we used a two-way ANOVA. We examine the effect of feedback presence and embedded points. It showed significant differences in customer engagement, with higher engagement in service with feedback than service without feedback $\left(M_{\text {wit__int }}=4.69\right.$ vs. $M_{\text {without_int }}=4.28$; $F(1,209)=5.95, p<0.05)$. The results also same in the intention to use, showing higher use intention in service with interactive feedback $\left(M_{\text {with } \_ \text {int }}=5.55\right.$ vs. $\left.M_{\text {without_int }}=5.14 ; F(1,209)=6.62, p<0.05\right)$. The results are consistent with H1a and $\mathrm{H} 1 \mathrm{~b}$ as shown in Figure 2.

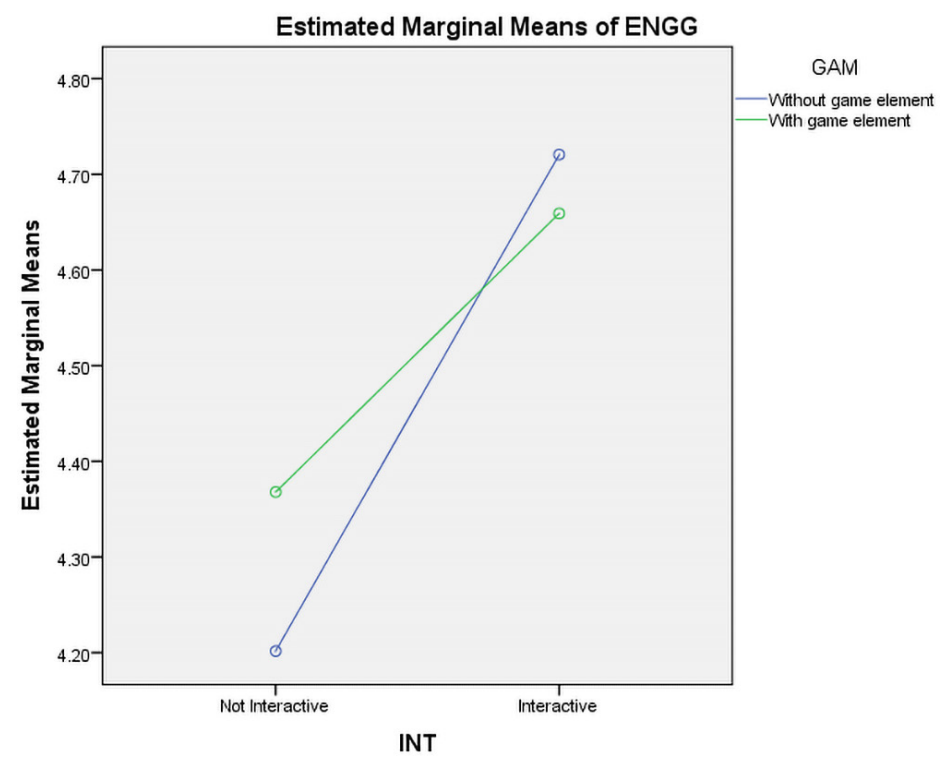

Figure 2. The effect of proposed engagement mechanics to user engagement

Next, participants found either with or without embedded points are similarly engaging $[F(1,209)=0.64, p>0.05]$ and trigger them to use online co-design service $[F(1,209)=1.11, p>0.05]$. It is quite unexpected that our results rejected $\mathrm{H} 2 \mathrm{a}$ and $\mathrm{H} 2 \mathrm{~b}$, showing that additional game elements did not affect user engagement with the co-design service, as well as their intention to use. Further, no other main or interaction effects were significant.

To test the robustness, we check the effects of age, gender, computer use frequency, and past experience in using the service but results show no significant covariates effects. Thus, demographic information was excluded from further analyses for parsimony. 
Following up the result from the first hypothesis test, we examined possible moderation effect lies in the relationship. We examined user innovativeness as predicted moderator, using a bootstrapping method by Hayes' (2013) PROCESS macro model 1 . We used interactive feedback $(1=$ with interactive feedback, $0=$ no interactive feedback) as an independent variable, intention to use as a dependent variable, and user innovativeness as moderators. The proposed moderators were continuous variables, thus, we employed floodlight (Johnson Neyman, JN) technique (Spiller, Fitzsimons, Lynch, \& McClelland, 2013) due to its robustness in seeking the turning points for where precisely the absolute value of moderators (Krishsna, 2016).

Regarding the conditional effect, when user innovativeness is lower (-1 SD), use intention with additional interactive feedback is higher than without interactive feedback $[b=0.567, S E=0.21,95 \% C I(0.152,0.982), p<0.05]$ as shown in Figure 3. In contrast, when user innovativeness is high (+1 SD), either with or without additional interactive feedback would not significantly affect user intentions $[b=0.126, S E=0.211,95 \% C I(-0.291,0.544), p>0.05]$.

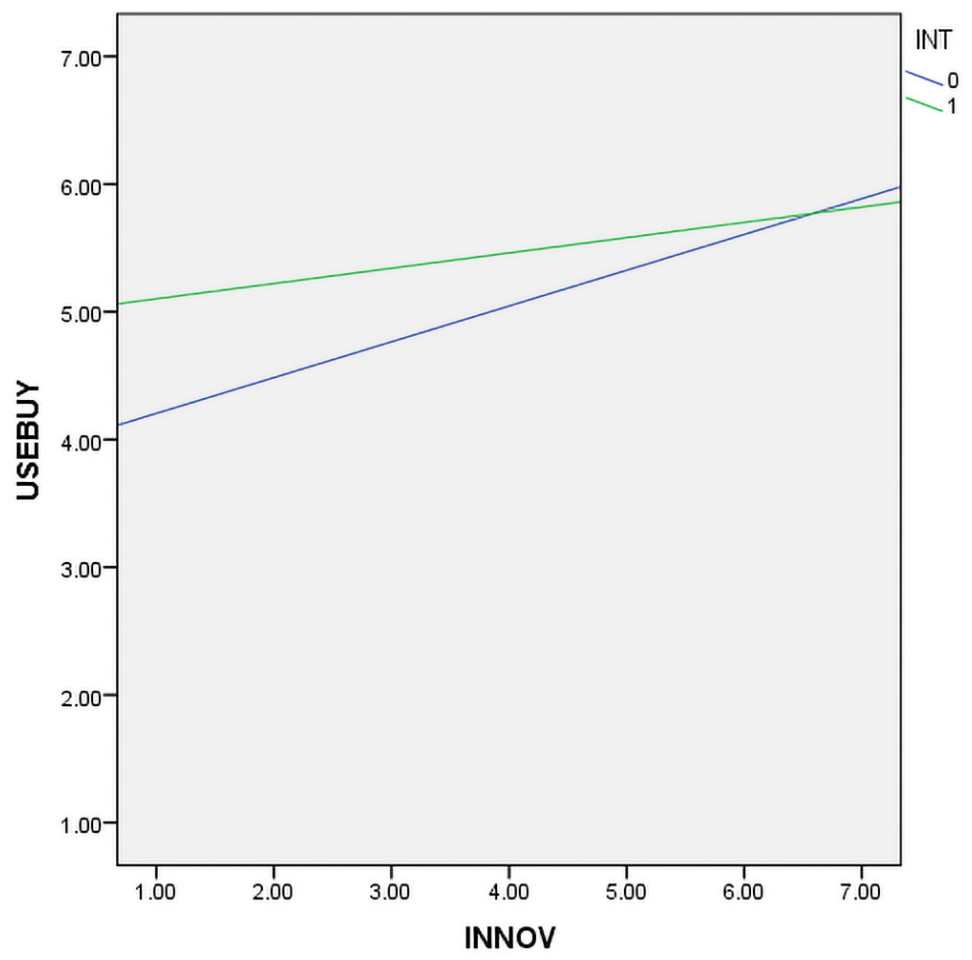

Figure 3. Moderating effect of user innovativeness between different level of interactive feedback 
The $\mathrm{JN}$ technique showed user innovativeness, at the value of 4.72 , is the turning point from significant to non-significant. In other words, when user innovativeness is below 4.72, user exposed with interactive feedback will have more intention to use compared to without interactive feedback. This result is consistent with H3a, highlighting that interactive feedback between customer and service provider are valuable. Particularly, it can improve a user who is less innovative to improve their intentions to use the online co-design service.

We employed the similar technique as the prior procedure to test the moderating effect of user innovativeness on game elements and user intention. However, JN shows no intersection points between the relationships rejecting the possibility of moderating effect of game elements. It is quite surprising that additional game elements have no significant impact on the various level of innovativeness. This result is in line with the arguments that gamification not always work positively in all online service context (Hamari, Koivisto, \& Sarsa, 2014).

\section{DISCUSSIONS AND IMPLICATIONS}

Our analysis shows that a co-design service that provides interactive contact with the service provider is more likely to create higher engagement and use intention. This is in line with flow theory, which posits that when a user is experiencing involvement through an engagement mechanism, their intention to use will increase. This also generates a positive result - when a service provider creates a platform that enables them to interact with the customer, the customer will perceive it as more valuable.

In line with our proposed theory on SDL, relevant meanings are created by the experiences a customer has over time (Payne et al., 2008). Specifically, Payne et al. (2008) emphasise the need to view the provider-customer relationship as a longitudinal, dynamic, and interactive set of experiences and activities performed by both parties. The encounter process involves a series of two-way interactions and transactions between the customer and the supplier. Ballantyne and Varey (2006) persuasively argue for a dialogical orientation so that value is co-created via dialog and learning. Communications should aim to influence customer and service provider to help customers better utilise both their own resources and those of the supplier. This concept supports our arguments, showing that interaction with the service provider is an effective mechanism for engaging users in the cocreation process. 
We also show that user innovativeness plays a vital role in the online co-design service. The differences in user innovativeness levels moderate the existence of interactive feedback in customer use intention. On the other hand, lower innovativeness might also cause by other personal factors such as education level and familiarity with various type of web service. Our results show that interactive feedback is useful for the less innovative customer. However, when customer innovativeness increases, they might not be affected; either there is or is not additional assistance from the service provider. This supports our predictions that interactivity is more valuable for users with lower innovativeness. A user with higher innovativeness is willing to explore the co-design website by him/herself. Thus, the presence of feedback does not affect them significantly. People with lower innovativeness might need guidance and triggers to immerse them in the codesign process. Thus, interaction with the service provider is valued and improves the customer's engagement and intention to use.

In addition, we find that additional game elements have no significant effect on user engagement and intention to use the online co-design service. This is quite surprising, since most gamification literature suggests that embedded game mechanics will affect user engagement and use intention. One plausible explanation is by Hamari et al. (2014): gamification effect possibly has confounding factors exist, and they greatly dependent on the context in which the gamification is being implemented as well as the quality of users. This also suggests that the mere implementation of gamification mechanisms does not automatically lead to significant increases in use activity in the studied utilitarian service (Hamari, 2013). E-commerce sites, especially a co-design type of service, might be a challenging system to be gamified, as the users could be geared towards optimising monetary value. The customer coming to e-commerce sites would mainly buy online products aiming for resource efficiency (time and cost) rather than fun or enjoyment. The insignificant effect of adding game elements provides direction for future research. There could be a venue to address additional factors, such as the inclusion of functional utility (e.g., perceived benefit) or external factors (e.g., social influence).

This study provides both theoretical and practical contributions. Theoretically, this study addresses co-design practice through the lens of SDL to emphasise customer's role and interactions between actors. Practically, the results suggest the importance of providing interactive back-end service during the service encounter to help customers. This mechanism is even more valuable for less innovative customers. Therefore, customer profiling through simple questions to assess user innovativeness levels, prior experience, or technology efficacy at the beginning of the service could be beneficial. 


\section{CONCLUSION}

This research contributes to both theory and practice. In terms of theory, this research is the first to examine engagement mechanisms in online co-design platforms and link the elements of engagement mechanics that might affect customer use intentions. We find that interactive feedback increases customer engagement and use intention, and co-design stimulates customer innovativeness to co-create in the product development process. Our research also investigates the focal effect of user innovativeness, showing that interactive feedback is more useful for users with lower levels of innovativeness. The moderating effect of user innovativeness to gamification and use intention is not proven.

From a practical standpoint, this study has implications for marketers and online co-design service providers, particularly in designing co-design service platform. Kristensson et al. (2008) posit that during product development, a user involvement project should consider key strategies, such as identifying needs. For example, the service provider might map a user's profile with a simple question that assesses the user's level of innovativeness and customises the service. For a user with lower innovativeness, designers can provide additional assistance and expert feedback. On the other hand, providing more freedom to a user with higher innovativeness helps them express their ideas. Another implication in co-design web service is that frontline employees and back-end customer support play a major role in retaining customer engagement with the service.

\section{Limitations and Directions for Future Research}

We note several points that can be improved. First, co-design web service is quite new in e-commerce settings, especially when it comes to specific users' expectations. It could be a great future research direction to examine the effect of product or performance risk that might contribute to users' intention to use codesign web service.

Second, our research setting was taken in Indonesia, which has continuous growth of internet adoption, but the e-commerce market is not mature yet. Additionally, we found a natural limitation from our sampling that skewed towards younger and highly educated population. In fact, it reflects the demographic proportion of actual e-commerce customer. Future studies will benefit from investigating a comparison of different markets or user characteristics. 
Finally, this study focused on a specific product, namely clothing and fashion industry, which is currently available to ease participants embrace the scenario. Future research can conduct a comparison of a different type of offerings that need different innovativeness, such as food, house, or financial industries, which possibly require the distinct structure of engagement mechanics particularly in its game elements used. As it has been pointed out that the effects of gamification are substantially context-dependent, such as in which circumstances it is implemented and how users' use it (Hamari et al., 2014).

\section{ACKNOWLEDGEMENTS}

This work was supported by the Indonesia Endowment Fund for Education (LPDP), Ministry of Finance, Republic of Indonesia under grant number 20140812021562.

\section{APPENDIX - SCENARIO DESIGN}

\section{Scenario 1}

Imagine that you want a shirt to give it to your friend abroad. You want to buy it online so it will save some time, and then you are looking for an online shop which provides shirt with many model and material. You find a website called Ciptaloka (https://www. ciptaloka.com) and this is the first time you are visiting the site. It turns out that this website gives you a chance to design the shirt that you want in its website service. This website offers options of materials, colour, and model of shirt that you can choose by yourself. You are also able to add text or picture as you desired. You decide to buy a white short sleeve shirt. You want to make the shirt more special and want to add text "Asli Indonesia" and a picture of traditional puppet on the front side. After you designed it, you are also able to check how much the total price for your self-designed shirt, which is Rp.75.000,-. You feel that the price is reasonable and affordable, so you decide to buy the shirt.

\section{Scenario 2}

Imagine that you want a shirt to give it to your friend abroad. You want to buy it online so it will save some time, and then you are looking for an online shop which provides shirt with many model and material. You find a website called Ciptaloka (https://www. ciptaloka.com) and this is the first time you are visiting the site. It turns out that this website gives you a chance to design the shirt that you want in its website service. This website offers options of materials, colour, and model of shirt that you can choose by yourself. You are also able to add text or picture as you desired. You decide to buy a white short sleeve shirt. You want to make the shirt more special and want to add text "Asli Indonesia" and a picture of traditional puppet on the front side. But you are still confused with the 
font size for the shirt. The website provides a direct ask feature with their designer through online chat, so that you can consult directly while designing to get a really good result. After you designed, you are also able to check how much the total price for your self-designed shirt, which is Rp.75.000,-. You feel that the price is reasonable and affordable, so you decide to buy the shirt.

\section{Scenario 3}

Imagine that you want a shirt to give it to your friend abroad. You want to buy it online so it will save some time, and then you are looking for an online shop which provides shirt with many model and material. You find a website called Ciptaloka (https://www. ciptaloka.com) and this is the first time you are visiting the site. It turns out that this website gives you a chance to design the shirt that you want in its website service. This website offers options of materials, colour, and model of shirt that you can choose by yourself. You are also able to add text or picture as you desired. You decide to buy a white short sleeve shirt. You want to make the shirt more special and want to add text "Asli Indonesia" and a picture of traditional puppet on the front side. From the design you made, it turns out that you get additional points that can be accumulated. You are also able to save your design and share it to the social media. If your friends want a similar product, your point will be accumulated automatically. After you designed, you are also able to check how much the total price for your self-designed shirt, which is Rp.75.000,-. You feel that the price is reasonable and affordable, so you decide to buy the shirt.

\section{Scenario 4}

Imagine that you want a shirt to give it to your friend abroad. You want to buy it online so it will save some time, and then you are looking for an online shop which provides shirt with many model and material. You find a website called Ciptaloka (https://www. ciptaloka.com) and this is the first time you are visiting the site. It turns out that this website gives you a chance to design the shirt that you want in its website service. This website offers options of materials, colour, and model of shirt that you can choose by yourself. You are also able to add text or picture as you desired. You decide to buy a white short sleeve shirt. You want to make the shirt more special and want to add text "Asli Indonesia" and a picture of traditional puppet on the front side. But you are still confused with the font size for the shirt. The website provides a direct ask feature with their designer through online chat, so that you can consult directly while designing to get a really good result. From the design you made, it turns out that you get additional points that can be accumulated. You are also able to save your design and share it to the social media. If your friends want a similar product, your point will be accumulated automatically. After you designed, you are also able to check how much the total price for your self-designed shirt, which is Rp.75.000,-. You feel that the price is reasonable and affordable, so you decide to buy the shirt. 


\section{REFERENCES}

Agarwal, R., \& Prasad, J. (1998). A conceptual and operational definition of personal innovativeness in the domain of information technology. Information Systems Research, 9(2), 204-215. https://doi.org/10.1287/isre.9.2.204

Ballantyne, D., \& Varey, R.J. (2006). Creating value-in-use through marketing interaction: The exchange logic of relating, communicating and knowing. Marketing Theory, 6(3), 335-348. https://doi.org/10.1177/1470593106066795

Bauer, H.H., Falk, T., \& Hammerschmidt, M. (2006). eTransQual: A transaction processbased approach for capturing service quality in online shopping. Journal of Business Research, 59(7), 866-875. https://doi.org/10.1016/j.jbusres.2006.01.021

Brodie, R.J., Hollebeek, L.D., Jurić, B., \& Ilić, A. (2011). Customer engagement: Conceptual domain, fundamental propositions, and implications for research. Journal of Service Research, 14(3), 252-271. https://doi.org/10.1177/1094670511411703

Chathoth, P., Altinay, L., Harrington, R.J., Okumus, F., \& Chan, E.S. (2013). Coproduction versus co-creation: A process-based continuum in the hotel service context. International Journal of Hospitality Management, 32, 11-20. https://doi. org/10.1016/j.ijhm.2012.03.009

Csikszentmihalyi, M. (1977). Beyond boredom and anxiety. San Fransisco: JosseyBass.

Csikszentmihalyi, M., \& Rathunde, K. (1993). The measurement of flow in everyday life: Toward a theory of emergent motivation. In J.E. Jacobs (Ed.), Current theory and research in motivation, Vol. 40. Nebraska Symposium on Motivation, 1992: Developmental perspectives on motivation (pp. 57-97). Lincoln, NE, US: University of Nebraska Press.

Dabholkar, P.A., \& Bagozzi, R.P. (2002). An attitudinal model of technology-based self-service: moderating effects of consumer traits and situational factors. Journal of the Academy of Marketing Science, 30(3), 184-201. https://doi. org/10.1177/00970302030003001

Deterding, S., Dixon, D., Khaled R., \& Nacke L. (2011). From game design elements to gamefulness: Defining "gamification". Proceedings of the 15th International Academic MindTrek Conference: Envisioning Future Media Environments. New York: Association for Computing Machinery. https://doi. org/10.1145/2181037.2181040

Flatla, D., Gutwin, C., Nacke, L., Bateman, S., \& Mandryk, R. (2011). Calibration games: Making calibration tasks enjoyable by adding motivating game elements. In UIST 11: Proceedings of the 24th Annual ACM Symposium on User Interface Software and Technology (pp. 403-412), Santa Barbara, California, USA. https://doi. org/10.1145/2047196.2047248

Franke, N., \& Piller, F.T. (2003). Key research issues in user interaction with user toolkits in a mass customisation system. International Journal of Technology Management, 26(5-6), 578-599. https://doi.org/10.1504/ijtm.2003.003424

Ghose, S., \& Dou, W. (1998). Interactive functions and their impacts on the appeal of internet presence sites. Journal of Advertising Research, 38, 29-44. 
Goldsmith, R.E. (2002). Explaining and predicting consumer intention to purchase over the internet: An exploratory study. Journal of Marketing Theory and Practice, 10(2), 22-28. https://doi.org/10.1080/10696679.2002.11501913

Hair, J.F., Black, W.C., Babin, B.J., \& Anderson, R.E. (2014). Multivariate data analysis (7th Pearson new international ed.) Harlow: Pearson.

Hamari, J. (2013). Transforming homo economicus into homo ludens: A field experiment on gamification in a utilitarian peer-to-peer trading service. Electronic Commerce Research and Applications, 12(4), 236-245. https://doi.org/10.1016/j. elerap.2013.01.004

Hamari, J., Koivisto, J., \& Sarsa, H. (2014). Does gamification work? A literature review of empirical studies on gamification. In Proceedings of the 47th Annual Hawaii International Conference on System Sciences, HICSS 2014 (pp. 3025-3034). [6758978] IEEE Computer Society Press. https://doi.org/10.1109/hicss.2014.377

Hayes, A.F. (2013). An index and test of linear moderated mediation. Multivariate Behavioral Research, 50(1), 1-22. https://doi.org/10.1080/00273171.2014.9626 83

Koskela-Huotari, K., Friedrich, P., \& Isomursu, M. (2013). Jungle of “co" (working paper). In Proceedings of the Naples Forum on Service, 18-21 June 2013, Ischia, Italy.

Koufaris, M. (2002). Applying the technology acceptance model and flow theory to online consumer behavior. Information Systems Research, 13(2), 205-223. https://doi. org/10.1287/isre.13.2.205.83

Krishna, A. (2016). A clearer spotlight on spotlight: Understanding, conducting and reporting. Journal of Consumer Psychology, 26(3), 315-324. https://doi. org/10.1016/j.jcps.2016.04.001

Kristensson, P., Magnusson, P.R., \& Matthing, J. (2002). Users as a hidden resource for creativity: Findings from an experimental study on user involvement. Creativity and Innovation Management, 11(1), 55-61. https://doi.org/10.1111/14678691.00236

Kristensson, P., Matthing, J., \& Johansson, N. (2008). Key strategies for the successful involvement of customers in the co-creation of new technology-based services. International Journal of Service Industry Management, 19(4), 474-491. https:// doi.org/10.1108/09564230810891914

Kwon, O., Choi, K., \& Kim, M. (2007). User acceptance of context-aware services: Self-efficacy, user innovativeness and perceived sensitivity on contextual pressure. Behaviour \& Information Technology, 26(6), 483-498. https://doi. org/10.1080/01449290600709111

Laurel, B. (1993). Computers as theatre. Reading, MA: Addison-Wesley.

Lowyck, J., \& Pöysä, J. (2001). Design of collaborative learning environments. Computers in Human Behavior, 17(5-6), 507-516. https://doi.org/10.1016/s07475632(01)00017-6

Lusch, R.F., \& Vargo, S.L. (2014). Evolving to a new dominant logic for marketing. In R.F. Lusch, \& S.L. Vargo (Eds.), The service-dominant logic of marketing: Dialog, debate and directions (pp. 21-46). United Kingdom: Routledge. 
Lusch, R.F., Vargo, S.L., \& O’Brien, M. (2007). Competing through service: Insights from service-dominant logic. Journal of Retailing, 83(1), 5-18. https://doi. org/10.1016/j.jretai.2006.10.002

McDougal, S. (2012). Co-production, co-design and co-creation: What is the difference? Retrieved 12 April 2017 from http://www.stakeholderdesign.com/co-productionversus-co-design-what-is-the-difference/

Montes, S.D., \& Zweig, D. (2009). Do promises matter? An exploration of the role of promises in psychological contract breach. Journal of Applied Psychology, 94(5), 1243-1260. https://doi.org/10.1037/a0015725

Muntean, C.I. (2011). Raising engagement in e-learning through gamification. In Proceedings of 6th International Conference on Virtual Learning (pp. 323-329), Romania.

O’Brien, H.L., \& Toms, E.G. (2008). What is user engagement? A conceptual framework for defining user engagement with technology. Journal of the American Society for Information Science and Technology, 59(6), 938-955. https://doi.org/10.1002/ asi.20801

Opromolla, A. (2015). "Gamified" social dynamics in the interactive systems as a possible solution for increasing co-design of emerging services in smart territories.DC@, CHItaly.

Ostrom, A.L., Parasuraman, A., Bowen, D.E., Patrício, L., Voss, C.A., \& Lemon, K. (2015). Service research priorities in a rapidly changing context. Journal of Service Research, 18(2), 127-159. https://doi.org/10.1177/1094670515576315

Payne, A.F., Storbacka, K., \& Frow, P. (2008). Managing the co-creation of value. Journal of the Academy of Marketing Science, 36(1), 83-96. https://doi.org/10.1007/ s11747-007-0070-0

Piller, F., Schubert, P., Koch, M., \& Möslein, K. (2005). Overcoming mass confusion: Collaborative customer co-design in online communities. Journal of Computer-Mediated Communication, 10(4), JCMC1042. https://doi. org/10.1111/j.1083-6101.2005.tb00271.x

Prahalad, C.K., \& Ramaswamy, V. (2004). Co-creation experiences: The next practice in value creation. Journal of Interactive Marketing, 18(3), 5-14. https://doi. org/10.1002/dir.20015

Rodrigues, L.F., Costa, C.J., \& Oliveira, A. (2014). How gamification can influence the web design and the customer to use the e-banking systems. In Proceedings of the International Conference on Information Systems and Design of Communication (pp. 35-44). ACM. https://doi.org/10.1145/2618168.2618174

Romero, D., \& Molina, A. (2011). Collaborative networked organisations and customer communities: Value co-creation and co-innovation in the networking era. Production Planning \& Control: The Management of Operations, 22(5-6), 447472. https://doi.org/10.1080/09537287.2010.536619

San Martín, H., \& Herrero, Á. (2012). Influence of the user's psychological factors on the online purchase intention in rural tourism: Integrating innovativeness to the UTAUT framework. Tourism Management, 33(2), 341-350. https://doi. org/10.1016/j.tourman.2011.04.003 
Sanders, E.B.N., \& Stappers, P.J. (2008). Co-creation and the new landscapes of design. Co-Design, 4(1), 5-18.

Shaukat, M.M., Gonzalez, R., \& Saltou, K. (2014). Co-design: Product type and demographics. Paper presented at the Industrial Designers Society of America (IDSA) Education Symposium, Austin, United States.

Son, J., Sadachar, A., Manchiraju, S., Fiore, A.M., \& Niehm, L.S. (2012). Consumer adoption of online collaborative customer co-design. Journal of Research in Interactive Marketing, 6(3), 180-197. https://doi.org/10.1108/17505931211274660

Spiller, S.A., Fitzsimons, G.J., Lynch Jr, J.G., \& McClelland, G.H. (2013). Spotlights, floodlights, and the magic number zero: Simple effects tests in moderated regression. Journal of Marketing Research, 50(2), 277-288. https://doi. org/10.1509/jmr. 12.0420

Stevenson, J.S., Bruner, G.C., Kumar, A. (2000). Webpage background and viewer attitudes. Journal of Advertising Research, 40(1/2), 29-34. https://doi.org/10.2501/jar-401-2-29-34

Teo, H.H., Oh, L.B., Liu, C., \& Wei, K.K. (2003). An empirical study of the effects of interactivity on web user attitude. International Journal of Human-Computer Studies, 58(3), 281-305. https://doi.org/10.1016/s1071-5819(03)00008-9

Tsiotsou, R.H., \& Wirtz, J. (2012). Consumer behavior in a service context. In V. Wells, \& G. Foxall (Eds.), Handbook of developments in consumer behaviour (pp. 147-201). Cheltenham, UK: Edward Elgar. https://doi.org/10.4337/9781781005125.00012

Udwadia, F.E., \& Kumar, K.R. (1991). Impact of customer construction in product/ service markets. Technological Forecasting and Social Change, 40(3), 261-272. https://doi.org/10.1016/0040-1625(91)90056-1

Ulrich, P.V., Jo Anderson-Connell, L., \& Wu, W. (2003). Consumer co-design of apparel for mass customization. Journal of Fashion Marketing and Management: An InternationalJournal,7(4),398-412.https://doi.org/10.1108/13612020310496985

Vargo, S.L., \& Lusch, R.F. (2004). Evolving to a new dominant logic for marketing. Journal of Marketing, 68(1), 1-17. https://doi.org/10.1509/jmkg.68.1.1.24036

Vargo, S.L., \& Lusch, R.F. (2016). Institutions and axioms: An extension and update of service-dominant logic. Journal of the Academy of Marketing Science, 44(1), 5-23. https://doi.org/10.1007/s11747-015-0456-3

Vargo, S.L., Maglio, P.P., \& Akaka, M.A. (2008). On value and value co-creation: A service systems and service logic perspective. European Management Journal, 26(3), 145-152. https://doi.org/10.1016/j.emj.2008.04.003

Verhoef, P.C., Reinartz, W.J., \& Krafft, M. (2010). Customer engagement as a new perspective in customer management. Journal of Service Research, 13(3), 247-252. https://doi.org/10.1177/1094670510375461

Voorberg, W.H., Bekkers, V.J., \& Tummers, L.G. (2015). A systematic review of cocreation and co-production: Embarking on the social innovation journey. Public Management Review, 17(9), 1333-1357. https://doi.org/10.1080/14719037.2014 .930505 
Webster, J., \& Hackley, P. (1997). Teaching effectiveness in technology-mediated distance learning. Academy of Management Journal, 40(6), 1282-1309. https://doi. org/10.5465/257034

Zhang, T., Lu, C., \& Kizildag, M. (2017). Engaging generation-Y to co-create through mobile technology. International Journal of Electronic Commerce, 21(4), 489-516. https://doi.org/10.1080/10864415.2016.1355639 